\title{
WACANA HUKUM INDONESIA SEBUAH PERSPEKTIF KEBAHASAAN
}

\author{
Sultan
}

\begin{abstract}
ABSTRAK
Tulisan ini betujuan untuk mendeskripsikan bentuk-bentuk kesalahan berbahasa dalam wacana hukum Indonesia (WHI) pada surat perjanjia. Dalam wacana hukum, penulis menemukan beberapa kesalahan berbahasa dalam bentuk kesalahan penggunaan tanda baca, struktur morfologi pada peroses pemajmukan, sintaksis dalam bentuk struktur kalimat yang pannjang, dan kesalahan dalam pembuatan kalimat yang efektif.
\end{abstract}

\section{PENGANTAR}

Bahasa merupakan alat untuk berkomunikasi dan berinteraksi bagi seluruh lapisan masyarakat. ia berkembang selaras dengan perkembangan kehidupan sosial, karena memiliki sifat yang dinamis. Di samping itu, bahasa memiliki dua lapisan, yakni lapisan bentuk dan makna. Makna sebuah bahasa akan dipengaruhi oleh struktur yang melakat di dalamnya. Sehingga kelengkapan atau kesatuan antara struktur dan makna bahasa yang dimunculkan dalam berkomunikasi disebut wacana discourse. Wacana merupakan tataran tertinggi dalam struktur kebahasaan setelah paragraf, tetapi wacana tidak harus berbentuk pragraf yang utuh, karena yang menjadi ukuran sebuah wacana adalah kelengkapan dan kesempurnaan makna yang terkandung di dalamnya.

Wacana dilihat dari pengungkapannya di bagi dua yaitu wacana lisan dan wacana tulisan. Wacana lisan dipakai dalam peroses komunikasi verbal antar personal dan cenderung kurang terstruktur (gramatikal), jarang menggunakan piranti hubung (alat kohesi) serta berstruktur topik-komen. sementara wacana tulisan ditampilkan dalam bentuk teks dan terstruktur subjek-predikat. Munculnya wacana tulisan berbentuk teks merupakan perwujudan dari bahasa lisan, karena wacana lisan/teks dianggap sebagai media komunikasi yang efektif terutama dalam komunikasi formal. Keefektifan teks dilihat dari keutuhan bentuk dan makna bahasa yang terdapat di dalamnya. Wacana tulisan/teks banyak dimanfaatkan dalam instansi-instansi pemerintah, misalkan dalam bentuk surat manyurat, pembuatan undangundang, hukum dan lain sebagainya.

Pembuatan hukum atau undang-undang akan menggunakan bahasa resmi atau bahasa persatuan, dan setiap Negara memiliki bahasa resmi sebagai bahasa pengantar atau lingua franca. Bangsa Indonesia menggunakan bahasa Indonesia menjadi bahasa resmi untuk seluruh lapisan masyarakat, dan digunakan di setiap bidang, baik di bidang perdagangan, politik, pendidikan, pengadilan dan bidang-bidang lainnya. Idealnya penggunaan bahasa Indonesia dalam komunikasi formal akan menggunakan kaidah atau aturan kebahasaan yang telah ditentukan, seperti atauran penggunaan tanda baca, pembentukan kata, struktur kalimat dan unsur-unsur yang terdapat dalam sebuah paragraf. hal ini bertujuan untuk memudahkan dan tidak mengaburkan pemahaman dalam memahami makna komunikasi formal. Tetapi dalam kenyataannya masih banyak kesalahan-kesalahan berbahasa yang terdapat dalam komunikasi formal pada wacana tulisan. Misalkan keslahan dalam bahasa hukum pada surat perjanjian.

Surat perjanjian adalah surat yang dibuat oleh dua pihak yang telah sepakat untuk 
suatu urusan. Jenis surat perjanjian ada bermacam-macam, misalnya perjanjian jual beli, perjanjian sewa beli, perjanjian sewa-menyewa, perjanjian kerja, dan perjanjian pinjaman uang. Surat perjanjian dibuat sebagai bukti autentik adanya ikatan kedua belah pihak dan untuk menghindari persengketaan di kemudian hari. Anatomi surat perjanjian terdiri dari (a) judul, (b) pembukaan, (c) komparisi, (d) premis/dasar pertimbangan, (e) isi perjanjian, (f) penutup, dan (g) tanda tangan dan lampiran (Widjaja 2004).

Tulisan ini bertujuan untuk membicarakan tentang kasus-kasus kesalahan berbahasa dalam penyusunan bahasa hukum yang terdapat dalam surat perjanjian. Adapun jenis-jenis kesalahan tersebut akan ditijau dari kaidah atau tata bahasa baku bahasa Indonesia, sehingga menjadi bahasa yang baik dan benar. Karena bentuk bahasa akan berpengaruh terhadap makna yang di munculkan dalam penggunaannya.

\section{BENTUK-BENTUK KESALAHAN BERBAHASA DALAM WACANA HUKUM PADA SURAT PERJANJIAN}

Pengungkap pemakaian bahasa hukum dalam ketiga surat perjanjian, ditemukan beberapa pemakaian bahasa yang tidak benar, yang meliputi pemakaian ejaan dan tanda baca, pemakaian bentuk jamak diikuti pengulangan kata, pemakaian kata yang bersinonim, pengaruh unsur bahasa Inggris, pemakaian kata yang bersinonim, pemakaian bahwa di depan Subjek, pemakaian bentuk kata yang tidak sejajar, pemakaian kalimat yang panjang, dan pemakaian Dalam Hal dan Maka.

\section{KESALAHAN DALAM PENGGUNAAN PUNGTUASI ATAU TANDA BACA}

Bahasa ilmiah hendaknya memperhatikan penulisan ejaan dan tanda baca yang benar. Penulisan ejaan dan tanda baca yang benar menandakan penulis memperhatikan kaidah-kaidah kebahasaan dan mampu menggunakannya secara tepat untuk menyatakan maksudnya. Kadang kala pemakaian tanda baca yang tidak tepat dapat mengakibatkan makna yang disampaikan berubah. Salah satu tanda baca yang sering digunakan di dalam bahasa hukum, khususnya di dalam surat perjanjian adalah titik koma.Terlepas dari struktur kalimatnya, perhatikan contoh (1) berikut.

(1) Bahwa Para Pihak masing-masing dalam kedudukannya sebagaimana tersebut di atas terlebih dahulu menerangkan hal-hal sebagai berikut:

- Bahwa Pihak Pertama merupakan perusahaan yang bergerak dibidang asuransi jiwa;

Dalam kaidah bahasa Indonesia, tanda titik dua diganti titik satu pada kalimat lengkap yang diikuti perincian berupa kalimat lengkap pula, dan perincian diakhiri tanda titik (Utorodewo, Felicia N. dkk. 2004). Oleh karena itu, pada kalimat pertama bukan titik dua yang mengakhiri kalimat, melainkan titik satu karena perincian berikutnya, yaitu kalimat kedua, merupakan kalimat yang sudah lengkap pula (mengandung unsur Subjek-PredikatPelengkap).

Di samping titik dua, penulisan di agaknya juga masih belum diperhatikan oleh penulisnya. $D i$ - ditulis menyambung jika kata yang mengikutinya merupakan verba (kata kerja). Kata berimbuhan di- sebagai awalan dapat diubah ke dalam bentuk kalimat aktif. Contoh: divonis-memvonis. Jika tidak berdampingan dengan verba, di ditulis terpisah, misalnya di pengadilan, di atas. Dengan demikian, kalimat kedua pada contoh (1) dibidang diperbaiki menjadi di bidang.

Contoh pemakaian tanda titik dua yang kurang tepat masih dapat dilihat pada (2) berikut ini.

(2) Tanpa persetujuan tertulis dari BANK, selama kredit belum lunas DEBITUR tidak diperkenankan untuk:

a. Menerima Kredit dari Bank lain, 
b. Mengikatkan diri sebagai penjamin (borg) terhadap pihak ketiga.

Tanda baca titik dua seharusnya tidak muncul pada unsur-unsur yang masih merupakan bagian dari kalimat yang bukan memberi penjelasan. Karena masih merupakan bagian dari kalimat, setelah titik dua tidak perlu diawali dengan huruf kapital layaknya awal kalimat. Juga kata lain di dalam kalimat yang bukan awal kalimat atau nama orang/tempat, tidak perlu ditulis huruf kapital; begitu pula kata-kata dari bahasa asing sebaiknya ditulis dengan huruf miring. Berikut perbaikan contoh (2).

(2a) Tanpa persetujuan tertulis dari bank, selama kredit belum lunas, debitor tidak diperkenankan untuk

a. menerima kredit dari bank lain,

b. mengikatkan diri sebagai penjamin (borg) terhadap pihak ketiga

\section{KESALAHAN DALAM BENTUK MORFOLOGI}

Morfologi merupakan ilmu yang mengkaji tentang proses pembentukan kata. Dalam hal ini, kesalahan yang terdapat dalam tulisan surat perjanjian ini adalah pelanggaran terhadap kaidah afiksasi dan reduplikasi atau pengulangan. Afiksasi merupakan peroses pembubuhan imbuhan pada sebuah kata baik di akhir, di tengah dan di akhir kata dasar. Sementara reduplikasi merupakan peroses pengulangan kata dasar baik secara seluruhan, sebagian dan berubah bunyi. Konsep atau tujuan pengulangan adalah untuk memberikan penekanan terhadap makna yang akan disampaikan, tetapi dalam kaidah pengulangan tidak boleh di ikuti dengan kata-kata yang memiliki kesamaan, dengan artian kata tersebut sama-sama memberikan penegasan, misalkan untuk menyatakan bentuk jamak di dalam bahasa Indonesia digunakan kata bermakna jamak, seperti beberapa, para, semua, atau kata bilangan. Ketika bentuk jamak itu digunakan, nomina yang yang menyertainya tidak lagi diulang katanya.

(3) a. Selalu mentaati dan melaksanakan semua peraturan perundang-undangan yang berlaku, termasuk tetapi tidak terbatas kepada, seluruh ketentuan-ketentuan yang berlaku serta sesuai standar profesionalisme, etika kerja dan kode etik yang lazim sebagai Tenaga Pemasaran di Indonesia.

(4) DEBITUR dengan ini berjanji dan mengikat diri untuk mensahkan semua tindakantindakan hukum...

Dalam contoh (3), selain kesalahan ejaan mentaati, yang seharusnya menaati, ditemukan seluruh ketentuan-ketentuan dan contoh (4) semua tindakan-tindakan. Supaya lebih hemat penggunaan katanya, diperbaiki masing-masing menjadi seluruh ketentuan dan semua tindakan. Munculnya bentuk kesalahan dalam surat perjanjian tersebut telah melanggar ketentuan atau kaidah bahasa indoesaia yang baik dan benar.

Dalam surat perjanjian kredit ditemukan pemakaian kata yang makna dan fungsinya sama, seperti adalah merupakan, seperti terlihat pada contoh berikut.

(5) Daftar pembayaran berikut perubahan-perubahannya adalah merupakan satu kesatuan yang tidak terpisahkan dari perjanjian kredit ini.

Sebaiknya, kalimat (5) diperbaiki dengan menggunakan salah satu di antara kedua kata tersebut, yaitu adalah atau merupakan. Apabila kedua kata itu muncul dalam satu tempat akan terjadi pemborosan leksikal dan akan menyebabkan tulisan menjadi tidak efektif.

\section{KESALAHAN DALAM BENTUK SINTAKSIS}

Sintaksis merupakan bagian ilmu bahasa yang mengkaji tentang struktur kalimat, karena kalimat yang baik harus memiliki struktur yang terdiri daru susuna subjek dan predikat (Ramlan 2007:24). Kemudian dalam struktur kebahasaan harus memiliki kesejajaran bentuk 
mengacu pada kesejajaran unsur-unsur di dalam kalimat sehingga memudahkan pemahaman pengungkapan pikiran (Alwi 2001). Bentuk kata yang sejajar lazim muncul pada kalimat yang membutuhkan rincian atau penjelasan; setiap rincian menggunakan bentuk atau pola kata yang sama. Perhatikan contoh (6).

(6) Perjanjian ini akan berakhir secara otomatis bilamana:

a. Berakhirnya jangka waktu Perjanjian ini.

b. Para Pihak setuju dan sepakat bersama-sama untuk mengakhiri Perjanjian ini.

c. Pihak Pertama sudah tidak lagi beroperasi dan atau menjalankan kegiatan usaha utamanya, atau Pihak Pertama dinyatakan pailit/bangkrut oleh Pengadilan, atau Pihak Pertama dibubarkan oleh keputusan rapat pemegang saham Pihak Pertama.

Pada awal setiap rincian terlihat bentuk atau pola yang tidak sama. Rincian a tidak diawali dengan Subjek seperti halnya b dan c yang mempunyai unsur Subjek: Para Pihak dan Pihak Pertama. Oleh karena itu, rincian dalam a perlu ditambahkan Subjek. Selain itu, jika masing-masing rincian a $-\mathrm{c}$ sudah berbentuk kalimat, hal itu berarti kalimat pengantar ke rincian, yaitu Perjanjian ini akan berakhir secara otomatis bilamana: juga harus merupakan kalimat yang lengkap. Agar sempurna sebagai kalimat, perbaikan yang sesuai, misalnya sebagai berikut.

(6a) Perjanjian ini akan berakhir secara otomatis bilamana terjadi kondisi-kondisi berikut.

a. Jangka waktu perjanjian ini// berakhir.

b. Para Pihak// setuju dan sepakat bersama-sama untuk mengakhiri perjanjian ini.

c. Pihak Pertama// sudah tidak lagi beroperasi dan atau menjalankan kegiatan usaha utamanya, atau Pihak Pertama dinyatakan pailit/bangkrut oleh pengadilan, atau Pihak Pertama dibubarkan oleh keputusan rapat pemegang saham Pihak Pertama.

\section{PELANGGARAN KAIDAH KALIMAT EFEKTIF}

Kalimat efektif merupakan kalimat yang mudah dipahami dan memiliki struktur yang lengkap serta menggunakan bahasa yang lugas (Sirulhak 2008:45), adapun kalimat yang panjang akan sulit dipahami maknanya. Hal tersebut terjadi karena ada beberapa gagasan di dalam satu kalimat yang ditumpuk-tumpuk, seperti tampak pada contoh data berikut.

(7)

1. Selama Kredit tersebut diatas belum lunas, maka barang jaminan tersebut harus dipertanggungkan oleh DEBITUR terhadap bahaya kebakaran, kerusakan, kecurian atau bahaya lainnya yang dianggap perlu oleh BANK pada maskapai asuransi yang disetujui oleh BANK, untuk jumlah dan dengan syarat-syarat yang dianggap baik oleh BANK, dengan ketentuan bahwa premi asuransi dan biaya lain yang berkenaan dengan penutupan asuransi tersebut dipikul oleh DEBITUR dan dalam polis asuransi BANK ditunjuk sebagai pihak yang berhak untuk menerima segala pembayaran berdasarkan asuransi itu (Banker's Clause).

2. Apabila perpanjangan asuransi sebagaimana dimaksud butir 2 di atas diurus oleh DEBITUR, maka DEBITUR wajib telah mengajukan permohonan perpanjangan asuransi selambat-lambatnya dalam jangka waktu 1 (satu) bulan sebelum tanggal jatuh tempo polis asuransi, dan polis perpanjangan asuransi harus telah diserahkan oleh DIBITUR kepada BANK selambat-lambatnya pada tanggal jatuh tempo polis asuransi yang diperpanjang, demikian dengan ketentuan bahwa apabila pada tanggal jatuh tempo polis asuransi tersebut, DEBITUR tidak/belum menyerahkan polis perpanjangan asuransi, maka DEBITUR dengan ini memberi kuasa kepada BANK, tanpa BANK berkewajiban untuk melaksanakannya, untuk memperpanjang asuransi tersebut di atas biaya DEBITUR.

Kalimat 1. di atas berjumlah 80 kata. Ada beberapa gagasan yang dikemukakan di 
dalam kalimat itu, yaitu

Barang jaminan dipertanggungkan oleh debitor terhadap bahaya kebakaran, kerusakan, kecurian, atau bahaya lainnya pada maskapai asuransi yang disetujui oleh bank,

Ketentuan pertanggungan adalah premi asuransi dan biaya lain berkenaan dengan penutupan asuransi dipikul oleh debitor;

Di dalam polis asuransi terdapat klausul tentang hak bank untuk menerima segala pembayaran berdasarkan asuransi itu.

Seperti kalimat 1 yang cukup panjang, kalimat 3 di atas terdiri dari 91 kata. Dalam satu kalimat itu ada beberapa pokok pikiran yang ingin disampaikan penulisnya, yaitu

(1) debitor wajib mengajukan permohonan perpanjangan asuransi paling lambat satu bulan sebelum jatuh tempo polis asuransi;

(2) polis perpanjangan asuransi harus diserahkan debitor kepada bank paling lambat pada tanggal jatuh tempo polis asuransi yang diperpanjang;

(3) apabila pada tanggal jatuh tempo, debitor belum/tidak menyerahkan polis perpanjangan asuransi, debitor memberi kuasa kepada bank untuk melakukan perpanjangan;

(4) bank diberi kuasa, tetapi tidak berkewajiban melaksanakannya;

(5) biaya perpanjang asuransi ditanggung oleh debitor.

Sebuah kalimat, kendatipun panjang jika kaitan antarkalimatnya jelas, tidak akan menyulitkan untuk mencerna isinya. Kalimat 1 dan 3 pada contoh (7) menunjukkan ada kecenderungan untuk menghubungkan antargagasan dengan konjungsi dan, padahal tidak semestinya setiap gagasan digabungkan dengan dan. Berikut perbaikan yang disarankan untuk (7).

(7a)

1. Selama kredit tersebut di atas belum lunas, barang jaminan tersebut harus dipertanggungkan oleh debitor terhadap bahaya kebakaran, kerusakan, kecurian, atau bahaya lainnya yang dianggap perlu oleh bank pada maskapai yang disetujui oleh bank. Biaya premi asuransi dan lainnya yang berkenaan dengan penutupan asuransi tersebut dibebankan pada debitor. Bank berhak menerima segala pembayaran berdasarkan asuransi itu (banker's clause).

2. Apabila perpanjangan asuransi sebagaimana dimaksud butir 2 di atas diurus oleh debitor, debitor wajib telah mengajukan perpanjangan asuransi selambat-lambatnya 1 (satu) bulan sebelum tanggal jatuh tempo polis asuransi. Polis perpanjangan asuransi harus telah diserahkan kepada bank selambat-lambatnya pada tanggal jatuh tempo polis asuransi yang diperpanjang. Apabila pada tanggal jatuh tempo polis asuransi tersebut debitor tidak/ belum menyerahkan polis perpanjangan asuransi, debitor memberi kuasa kepada bank, tetapi bank tidak berkewajiban untuk melaksanakannya, untuk memperpanjang asuransi tersebut di atas dengan biaya debitor.

\section{KESLAHAN DALAM KALIMAT MAJEMUK}

Sugono (2009:215) mengatakan bahwa di dalam kenyataan penggunaan bahasa, terdapat sejumlah kalimat yang cukup berhasil dalam penyampaian informasi, tetapi dilihat dari segi kaidah, kalimat-kalimat itu tidak memenuhi syarat kalimat yang benar. Kalimat yang dimaksud adalah kalimat majemuk bertingkat yang tidak jelas unsur-unsurnya mana yang merupakan inti kalimat (induk kalimat) dan mana yang anak kalimat (penjelas induk kalimat). Anak kalimat lazim didahului oleh konjungsi dan induk kalimat tidak didahului oleh konjungsi.

\section{Pemakaian Dalam Hal dan Maka}

Dalam contoh (8) di bawah ini, dalam hal berperilaku sebagai konjungsi, yang sebenarnya menyatakan suatu kondisi atau keadaan yang belum tentu terjadi. Maknanya 
hampir mirip dengan jika, apabila. Adanya konjungsi itu menandakan ada anak kalimat. Anak kalimat tersebut diikuti dengan maka sesudah koma, yang juga sebagai anak kalimat karena diawali konjungsi maka. Oleh karena itu, kalimat (8) tidak dapat disebut kalimat majemuk bertingkat karena tidak ada informasi yang diutamakan sebagai induk kalimat.

(8) Dalam hal terjadi perbedaan penafsiran antara versi bahasa Inggris dan bahasa Indonesia, maka yang berlaku adalah bahasa Indonesia.

2. Pemakaian bahwa di depan Subjek

Konjungsi bahwa (dari bahasa Inggris whereas) merupakan konjungsi yang banyak digunakan sebagai awal dari pernyataan hukum. Akan tetapi, perlu diperhatikan tidak semua awal pernyataan dapat diawali dengan bahwa. Perhatikan contoh (8) berikut.

(8) Bahwa Para Pihak masing-masing dalam kedudukannya sebagaimana tersebut di atas terlebih dahulu menerangkan hal-hal sebagai berikut:

Di dalam kalimat pasif kata bahwa merupakan penanda bahwa unsur yang menyertainya adalah anak kalimat pengisi subjek, seperti Bahwa dia tidak bersalah//telah dibuktikan (Sugono 2009:46-47). Kalimat itu dapat dipermutasi menjadi Telah dibuktikan bahwa dia tidak bersalah. Bahwa juga merupakan penanda subjek yang berupa anak kalimat pada kalimat yang menggunakan adalah, merupakan, atau ialah, seperti Bahwa percobaan itu gagal//merupakan risiko dia. Oleh karena itu, penggunaan bahwa pada (8) sebaiknya ditiadakan sehingga dengan tegas kalimat itu menampakkan Subjek, yaitu Para Pihak masing-masing dalam kedudukannya sebagaimana tersebut di atas (lihat 8a).

(8a) Para Pihak masing-masing dalam kedudukannya sebagaimana tersebut di atas// terlebih dahulu menerangkan hal-hal sebagai berikut.

Kesalahan-kesalahan dalam penggunaak kaidah bahasa Indonesia pada wacana hukum dalam surat perjanjian tersebut menyebabkan ketidakjelasan makna yang disampaikan. Hal tersebut akan mengakibatkan munculnya interpretasi ganda atau berbeda antara penutur (pembuat aturan/hukum (perjanjia) dengan lawan tuturnya.

\section{KESIMPULAN}

Dari dokumen surat-surat perjanjian yang diamati terbukti bahwa penulis dokumen hukum belum menguasai kaidah bahasa Indonesia. Bahasa hukum Indonesia di dalam surat perjanjian yang diamati masih menunjukkan kesalahan yang klise, seperti ketidaktepatan dalam penggunaan ejaan, tanda baca, dan kalimat. Karena bahasa hukum merupakan produk yang diperuntukkan bagi masyarakat dari kalangan mana pun, bukan hanya orang dari kalangan hukum, seharusnya penyusun dokumen hukum lebih menyederhanakan penyampaian pesan atau maksud dari aturan atau pernyataan di dalam pasal-pasalnya sehingga pembaca lebih mudah dan cepat mencerna isinya. Penyampaian isi yang efektif perlu didukung oleh kaidah ejaan bahasa Indonesia yang benar. Penulis menyarankan agar ahli hukum adalah juga pemerhati bahasa Indonesia. 


\section{DAFTAR PUSTAKA}

Alwi, Hasan. 2001. Bahan Penyuluhan Bahasa Indonesia: Kalimat. Jakarta: Departemen Pendidikan Nasional.

Mahadi dan Sabaruddin Ahmad. 1979. Pembinaan Bahasa Hukum Indonesia. Badan Pembinaan Hukum Nasional Departemen Kehakiman. Jakarta: Binacipta.

-------. 1983. Bahasa Hukum Adat dalam Peta Bumi Bahasa-Hukum Nasional. Dalam Hukum dan Pembangunan No. 3 Tahun XIII Mei.

Murniah. 2007. Bahasa Hukum Rumit dan Membingungkan. Wawasan, 30 November.

Nasucha, Yakub, Muhammad Rohmadi, dan Agus Budi Wahyudi. 2009. Bahasa ndonesia untuk Penulisan Karya Tulis Ilmiah. Surakarta: Media Perkasa.

Ramlan. 2007. Sintaksis Bahasa Indonesia. Yogyakarta: Pustaka Pelajar

Sugono, Dendy. 2009. Mahir Berbahasa Indonesia dengan Benar. Jakarta: Gramedia Pustaka Utama.

Sirulhak, Ahmad. 2008. Bahasa Indonesia Perguruan Tinggi. Mataram: UNRAM Press

Utorodewo, Felicia N., Lucy R. Montolalu, L. Pamela Kawira. 2004. Diktat Bahasa Indonesia Sebuah Pengantar Penulisan Ilmiah. Depok. Program PDPT Universitas Indonesia.

Widjaja, I.G. Rai. 2004. Merancang Suatu Kontrak (Contract Drafting) Teori dan Paktik. Bekasi: Megapoin.

\section{Sumber Data}

Perjanjian Kerja Waktu Tertentu No. 001/KK-HRD/12/2009

Perjanjian Kredit No.: 52/2008.

Perjanjian Pemberian Pinjaman No. 006/HT-P/HKM/I/2009. 